Animal Health Research Institute, El Mansoura Lab.

\title{
ASSESSMENT OF SOME CHEMICAL ENVIRONMENTAL POLLUTANTS IN RAW MILK SAMPLES IN DAKAHLIA GOVERNORATE
} (With 2 Tables)

By

\author{
AZZA E.A. HASSAN and EL-SHAHAT A.F. \\ (Received at 22/10/2011) \\ عزة السبي على حسان ، الشحات أبو مسلم طوسون فرحات
}

تقيم بعض الملوثات الكيميائية البيئية فى اللبن الخام في محافظة الدقهلية

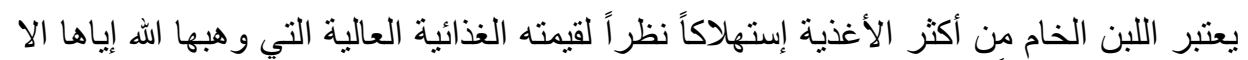

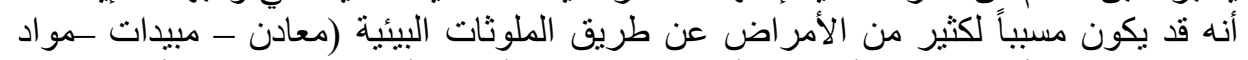

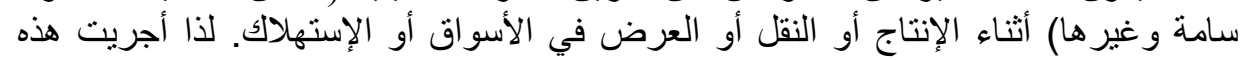

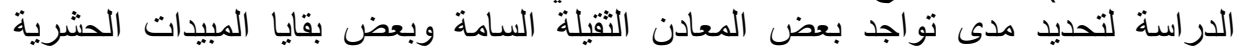

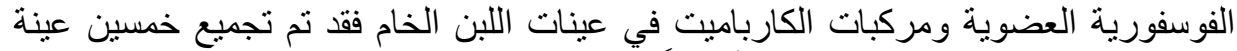

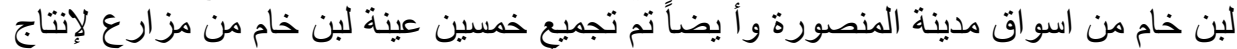

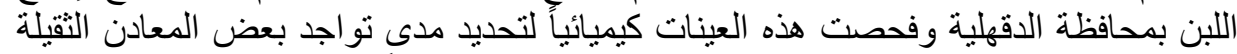

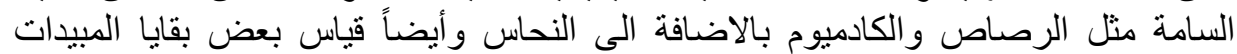

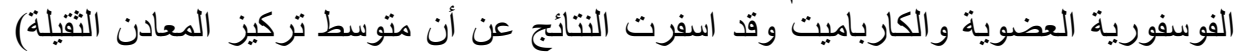

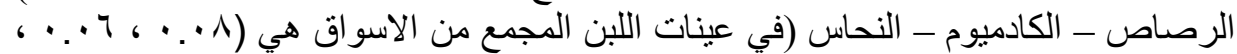

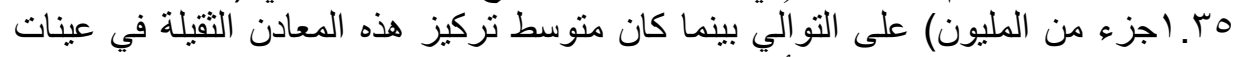

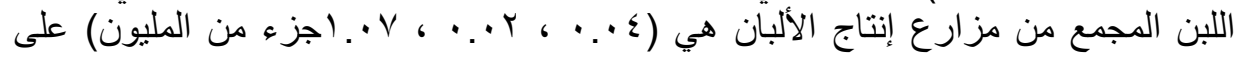

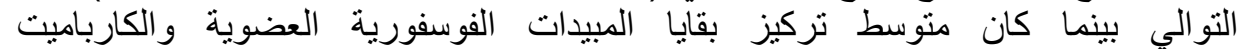

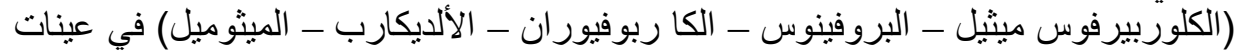

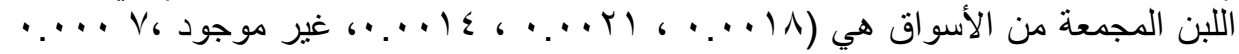

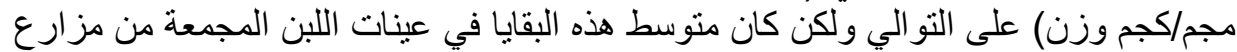

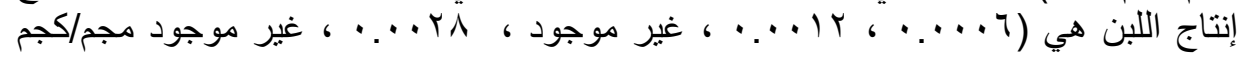

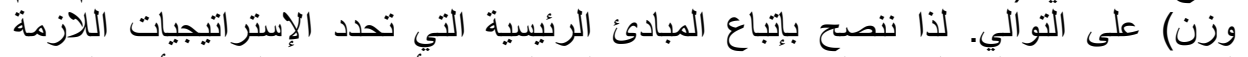

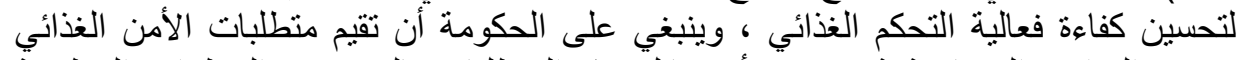

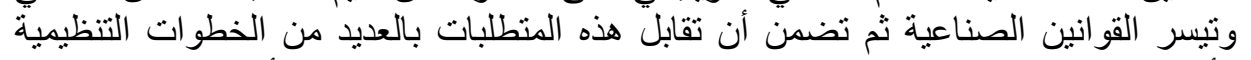

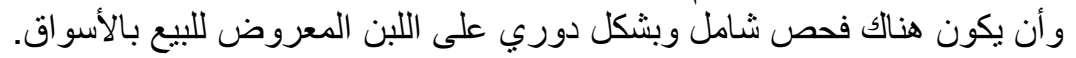




\section{SUMMARY}

A total of hundred random samples of raw milk were collected from the markets and from dairy farms in Dakahlia Governorate, fifty samples each. All milk samples were analysed for chemical contaminants to determine some heavy metals (lead, cadmium and copper), also to determine some pesticides and carbamate residues (chlorpyrifosmethyl, profenfos, carbofuran, aldicarb and methomyl). The obtained results showed the means concentration of heavy metals (lead, cadmium and copper) in milk samples collected from the markets were 0.08, 0.06 and $1.35 \mathrm{ppm}$ respectively. While the means concentration of lead, cadium and copper in samples collected from dairy farms were 0.04, 0.02 and $1.07 \mathrm{ppm}$ respectively. Regarding to pesticides and carbamate residues (chlorpyrifosmethyl, profenfos, carbofuran, aldicarb and methomyl) their mean concentrations were $0.0018,0.0021,0.0014$, not detected and $0.0007 \mathrm{mg} / \mathrm{kg}$ weight, respectively in milk samples collected from the markets, while the mean values for the samples collected from dairy farms were 0.0006, 0.0012, not detected, 0.0028 and not detected, respectively. So we advice to follow major principles that underlie strategies for improving the efficiency and effectiveness of food control: The efforts are focused on issues that pose the greatest risk. The government must establish food safety requirements, facilitate industry's compliance with these and then ensure that the requirements are through a range of regulatory measures and frequent examination of marketed milk.

Key words: Milk, heavy metals, pesticides, dairy farms.

\section{INTRODUCTION}

Milk is a basic food in the human diet both in its original form and as various dairy products, it can carry numerous xenobiotic substances (pesticides, drugs, disinfectants, metals and various environmental contaminants), which constitute a technological or risk factors for milk and dairy products (Bluthgen and Heeschen, 1997; Simsek et al., 2000), heavy metals as lead, cadmium and copper refers to any metalic element heavier than iron, they are natural components of the Earth's crust, they are dangerous because they tend to bio-accumulate (Licata et al., 2004).

Heavy metals can enter water supply by industrial wastes, or even from acidic rain breaking down soils and release heavy metal into 
water, these contaminants may present a potential hazard for human and animals health if exposure exceeds tolerable levels (Turi-szerletics and Patko, 2008). Heavy metals are persistent types of pollutants which cannot be destroyed by heat treatments or environmental degradation, so their persistence enhance their potential to reach and affect human being (Levensen and Barnard, 1988). Feeding animals with forage produced in contaminated areas results in increasing the concentration of heavy metals in milk and meat (Massanyi et al., 2001). Determination of the residual concentrations of metals in milk could be an important "direct indicator" of the hygienic status of the milk and/or of its derived products, as well as "indirect indicator" of the degree of pollution of the environment in which the milk was produced (Licata et al., 2004) Organophosphorus pesticides are usually esters of phosphoric acid, there is considerable structural diversity in the side chains among the commonly used organophosphorus. The side chains determine the toxicokinetics and toxicodynamics of pesticide poisoning (Moretto, 1998).

Organophosphorus pesticides can appear in milk due to several possible causes: Use of insecticides directly on dairy cattle for ectoparasites control, pasture, or animal feed manufactured from plant material that has been treated with insecticides and use of insecticides in stables or dairy factories. There are several reports of their presence in cow's milk (Kituyi et al., 1997). Residues of organophosphours have been reported in buffalo and pasteurized milk (El-Kohly et al., 2000; Salas et al., 2003). The present work was designed to determine the residual concentration of some heavy metals as lead, cadmium and cupper, also to determine some organophosphorus and carbamat, pesticides residual in raw milk as a servey for the knowledge of their possible hazardous residual limits for human consumption that must be avoided through different safety routs of healthy control measures.

\section{MATERIALS and METHODS}

\section{Detection of heavy metals in raw milk samples:}

A total of one hundred samples of raw milk were collected in clean polyethylene bottles from different markets in Mansoura City, Dakahlia Governorate and from private dairy farms in Dakahlia Governorate, (fifty samples of each locality). $5 \mathrm{ml}$ of each raw milk samples were digested by adding $10 \mathrm{ml}$ of conc. $\mathrm{HNO}_{3}$ solution and perchloric acid (1:1). The samples were digested overnight in a cold 
place followed by mild increasing in temperatures till heating at $100 \mathrm{C}^{\circ}$ in water bath for 4 hours, then 5 drops of $30 \% \mathrm{H}_{2} \mathrm{O}_{2}$ were added and heating was continued till the brown nitrous gases were expelled and the specimens become clear. After cooling, each digest was diluted to $25 \mathrm{ml}$ with deionized water and filtered through Wattman No. 42 filter paper. The clear filterate of each sample was kept in refrigerator to avoid evaporation. All samples were analyzed by using flame Atomic Absorption spectrophotometer for determination of lead, cadmium and copper according to AOAC (2004). This was done at Faculty of Science Mansoura University.

\section{Determination of pesticides residues in raw milk Samples:}

Fifty $\mathrm{ml}$ of milk were blended with ethylacetate for organophosphorus pesticides and with $10 \mathrm{ml}$ acetone for carbamate pesticides and sodium sulphate (50gm) was added and the mixture was shaken and then allowed to stand for 2-3 min. The upper layer was decanted, and $50 \mathrm{ml}$ aliquot was evaporated to dryness in a rotating evaporator at $35^{\circ} \mathrm{C}$. The residue was dissolved in $10 \mathrm{ml}$ hexane and then extracted with $2 \times 25 \mathrm{ml}$ acetonitrile saturated with hexane. Combined acetonitrile phase was evaporated to dryness. The residue was dissolved in $2 \mathrm{ml}$ of hexane.

The hexane extract after cleaning up was dried by passing through sodium sulphate anhydrous. The hexane extract was rotary evaporatored to few drops any quantitatively transferred to volumetric tube. The volume was adjusted to $\mathrm{lml}$ with hexane. (Naik et al., 2000). This was done at Faculty of Science, Mansoura University.

- Statistical analysis of variance (ANOVA) and t-test was carried out following the method described by (Kirkwood, 1989).

\section{RESULTS}

Table 1: Heavy metals concentrations in raw milk samples collected from dairy farms and markets in Dakahlia Governorate.

\begin{tabular}{|c|c|c|c|}
\hline \multirow{2}{*}{ Raw milk samples } & \multicolumn{3}{|c|}{ Heavy metals } \\
\cline { 2 - 4 } & $\begin{array}{c}\text { Lead } \\
(\mathrm{ppm})\end{array}$ & $\begin{array}{c}\text { Cadmium } \\
(\mathrm{ppm})\end{array}$ & $\begin{array}{c}\text { Copper } \\
(\mathrm{ppm})\end{array}$ \\
\hline Milk samples collected & 0.08 & 0.06 & 1.35 \\
from dairy farms & \pm 0.004 & \pm 0.003 & \pm 0.06 \\
\hline Milk samples collected & 0.04 & 0.02 & 1.07 \\
from the markets & \pm 0.003 & \pm 0.001 & \pm 0.2 \\
\hline
\end{tabular}


Table 2: Pesticide residues $(\mathrm{mg} / \mathrm{kg})$ in milk samples collected from dairy farms and markets in Dakahlia Governorate.

\begin{tabular}{|c|c|c|c|}
\hline \multirow{2}{*}{ Class } & Pesticide & $\begin{array}{c}\text { Ramples of milk } \\
\text { collected from } \\
\text { dairy farms. }\end{array}$ & $\begin{array}{c}\text { Samples of milk } \\
\text { collected from the } \\
\text { markets }\end{array}$ \\
\cline { 3 - 4 } & Chlorpyrifos & $\begin{array}{c}0.0006 \\
\pm 0.0001\end{array}$ & $\begin{array}{c}0.0018 \\
\pm 0.0002\end{array}$ \\
\hline Organophosphorus & $\begin{array}{c}0.0012 \\
\pm 0.0004\end{array}$ & $\begin{array}{c}0.0021 \\
\pm 0.0003\end{array}$ \\
\hline Organophosphorus & Profenfos & $\begin{array}{c}0.0014 \\
\pm 0.0003\end{array}$ \\
\hline Carbamate & Carbofuran & $\begin{array}{c}\text { ND } \\
\pm 0.0028\end{array}$ \\
\hline Oxime Carbamate & Aldicard & ND & $\begin{array}{c}0.0007 \\
\pm 0.0001\end{array}$ \\
\hline Oxime Carbamate & Methomyl & \multicolumn{2}{|c|}{} \\
\hline
\end{tabular}

\section{DISCUSSION}

Heavy metals are released into the environment by both natural and anthropogenic sources, especially mining, industrial activities and automobile exhausts (for lead). Poison or toxicity in animals occur frequently through exchange and co-ordination mechanisms (Duruibe et al., 2007).

Table 1 showed the mean value of heavy metals (lead, cadmium and copper) concentration in milk samples collected from dairy farms in Dakahlia Governorate were 0.04, 0.02 and 1.07 ppm respectively, while the mean concentration value of lead, cadmium and copper in milk samples collected from the markets in Dakahlia Governorate were 0.08, 0.06 and $1.35 \mathrm{ppm}$ respectively. According to the Egyptian standard (2001) the Acceptable permissible limit (APLS) for both lead and cadmium were the same as in milk $0.05 \mathrm{mg} / \mathrm{kg}$, there for the mean values of samples collected from the markets were slightly exceeded the permissible limit and not lied within the APLS. The presence of lead in milk samples may be due to various factors: Automobile vehicles along roads by gasoline burning of tetra ethyl lead content, fodder contamination, from lead based points climatic factors such as winds and the use of lead based pesticide compounds (Buk, 1970). Emam and 
El-Nabrawy (2008) found that the mean concentration of lead, cadmium and copper in raw milk collected from Sharkia Governorate were 1.970, 0.353 and $0.025 \mathrm{ppm}$, respectively. Meanwhile Licata et al. (2004) determined lead, cadmium and copper in cow's milk samples which were $1.32,0.02$ and $1.98 \mathrm{mg} / \mathrm{kg}$, as a mean value respectively.

Lead toxicity induced liver and renal dysfunction, the mode of toxic action through the combination with sulfhydrylcarboxy and imidazole containing protein molecules and induced CNS abnormalities as (convulsive seizures, circling, blindness and maniacal behavoirs), anaemia, increased reticulocytes (with basophilic stippling) and substantial functional renal damage with presence of tubular nuclear inclusion bodies (Klaassen et al., 1986). Long term exposure to cadmium lead to toxic effects which induced slight anaemia, lung disease and myocardial dysfunctions WHO (1980); INECAR (2000). Zn contained in food interferes with copper absorption system (Klaassen et al., 1986). International Dairy Federation (1991) recorded that 0.001 0.005 and $0.002-0.0008 \mathrm{mg} / \mathrm{kg}$ were the normal range of lead and cadmium in milk respectively.

The results of organophosphorus and carbamate pesticide analysis in the current wark represented by the determination of chlorpyrifos methyl, profenfos, carbofuran aldicarb and methomyl residues in raw milk samples from the markets and milk samples from dairy farms in Dakahlia Governorate: Table 2 showed chlorpyrifos, profenfos, carbofuran, aldicarb and metho myl residues in raw milk samples collected from Dakahlia Governorate markets were with the means of $0.0018,0.0021,0.0014$, not detected and $0.0007 \mathrm{mg} / \mathrm{kg}$ respectively, while samples of milk collected from dairy farms in Dakahlia Governorate were with the means of 0.0006, 0.0012, not detected, 0.0028 and not detected respectively.

Pagliuca et al. (2004) found that among more than 100 samples analyzed, 30\% were positive to (chlorpyriphos methyl) contamination from eight organophosphorus pesticides, but always below legal limits. These values permit quantification of the residues below legal limit: (10 $\mathrm{ppb}$ ) for chlorpyriphosmethyl pesticide. The European Commission (2003). The average recoveries of fortified organophosphorus pesticide residues $(10-50 \mathrm{ppb})$ ranges from $75.0 \%$ to $104.5 \%$ were determined in milk samples Schenck and Wagner (1995). Five carbamate insecticides aldicarb, MTMC, carbofuran, carbaryl and MIPC were determined in milk samples and the detected limits of 85 carbamate insecticides were $0.75-3.00 \mathrm{ng}$ ( $\mathrm{Li}$ and Wang, 1997). Both organophosphorus and 
carbamate were found in milk samples (cow's raw milk and market), indicated that their misuse in agriculture practices, all means concentration were below the maximum limits permitted by the European Union Mallatus et al. (1997).

While organophosphorus and carbamate were not detected in cow's milk samples, by Clascato et al. (2002). These results disagree with the obtained showed in Table 2. Di-Muccio et al. (1996) determined 24 organophosphorus pesticide residues in milk samples and found levels ranging from 0.02 to $1.11 \mathrm{mg} / \mathrm{kg}$. chlorpyrifos - methyl residues may be present in milk because of their use in crops destined for animal feed such as alfalfa, sorghum, soy and maize (Salas et al., 2003). The presence of these OP-pesticides contrasts with the opinion of Bluthgen and Heeschen (1997), who considered that metabolic breakdown of pesticide is rather quick and that there is only a rare chance to observe their residues in milk. El-Hoshy (1997) has detected the presence of chlorpyrifos - methyl residues in raw milk, also Bolles et al. (1999) considered that chlorpyrifos residues are rarely detected in food itmes for example, market milk. Chlorpyrifos is one of the OPpesticides with higher use in our country INE., (2000). The biosensors developed market it possible to detecte on chlorpyrifos and carbofuran in aqueous solution by cholinesterase sensors (Ivanov et al., 2003), our results were within the permissible limits of The European commission (2003), FAO (2005) and FAO (2008). Pesticides can appear in milk and dairy products due to several possible causes as the use of insecticides directly on dairy cattle for ectoparasite control or animal feed manufactured from plant material that has been treated with insecticides in stables or dairy factories. Pagliuca et al. (2004) determined eight pesticide residues in milk, widely used in agriculture. Some of pesticides residue were detected at lower levels, may be due to that were destroyed by acid produced by soil bacteria, reported by UNEP / IOC/ IAEA, (1989). Agricultural production may be adversely affected by flooding associated with natural disasters. When crop fields have been contaminated or damadge, assessments should be carried out to establish measures to reduce the risk of chemicals, hazardous and natural toxins (eg. Delayed harvesting, heat treatment or to assure disposal (FAO, 2005; WHO, 2005).

So we advice to follow major principles that underlie strategies for improving the efficiency and effectiveness of food control: that efforts are focussed on issues that pose the greatest risk. The government must establish food safety requirements, facilitate industry's compliance 
with these and then ensure that the requirements are through a range of regulatory measures and frequent examination of marketed milk.

\section{REFERENCES}

AOAC "Association of Official Analytical Chemists" (2004): Official Methods of Analysis $17^{\text {th }}$ ed. AOAC, Arlington, VA.

Bluthgen, A. and Heeschen, W.H. (1997): Principles for the toxicological evaluation of the residues in monograph on residues and contaminants in milk and milk products; International Dairy Federation: Brussels, Belgium.

Bolles, H.G.; Dixon, W.H.; Peterson, R.K.; Tomerlin, J.R.; Day, J.E. and Oliver, G.R. (1999): US. Market, basket study to determine residues of the insecticide chlorpyrifos. J. Agric. Food Chem., 47: $1817-1822$.

Buk, W.B. (1970): Lead and organic pesticide poisoning in cattle, J. Am. Vet. Med. Assoc., 156 (10): 1468-1472.

Clascato, C.H.; Gebara, A.B. and Spinosa, H.S. (2002): Pesticide residues in cow milk consumed in Sao Paulo City (Brazil). J. Eviron. Sci. Health B., 37 (4): 323-330.

Di-Muccio, A.; Pelosi, P.; Camoni, I.; Attard, B.D.; Dammarco, R.; Generali, T. and Ausili, A. (1996): Selective, solid-matrix dispersion extraction of organoposphate pesticide residues from milk. J. Chromatog. A., 754 (2); 496-506.

Duruibe, J.O.; Ogwuegbu, M.O. and Egwurugwu, J.N. (2007): Heavy metals pollution and human biotoxic effects. Inter. J. of Physical Sci., 2(5): 112-118.

Egyptian Standard (2001): Condensed milk. Egyptian Organization for Standerization and Quality Control. ES, 1830 and 1648.

El-Hoshy, S.M. (1997): Insecticide residues in milk and Influence of heat treatments and bacterial fermentation as safeguard against these pollutants. J. Assiut Med. Vet., 37: 141-155.

El-Kholy, A.F.; Afifi, A.M.; Ragab, A.A. and El-Baroty, G.S. (2000): Concentration of buffalo milk with residues of diazinon insecticide after spraying animals. Vet. Med. J. Giza., 48: 7-11.

Emam, E.E. and El-Nabarawy, E.A. (2008): Some studies on heamatological and some biochemical changes induced by heavy metal in cattle reared in Bahr El-Bakar region with special reference to its residues in milk. Assiut Vet. Med. J., 54 (116), 158-170. 
FAO (2005): Special event on impact of climate change, pests and diseases on food security and poverty reduction. Background Document. $31^{\text {st }}$ Session of the committee on World Security, 10.

FAO (2008): Expert Meeting on Bioenergy Policy, Markets and Trade and Food Security and Global Perspectives on Fule and Food Security FAO Headquarters, Rome, 18-20 February, Options for Decision Makers.

INE (2000): Characteristics de peligriosidad ambiental de plaguicidas. Manual de Trabajo. Instituto de Ecologiea. Secretaria de Medio Ambiente, Recursos Naturalesy Pesca (SEMARNAP), Mexico D.F.

Institute of Environmental Conservation and Research INECAR (2000): Position Paper Against Mining in Rapu-Rapu. Published by INECAR, Ateneo de Naga Univ., Philippines.

International Dairy Federation (IDF) (1991): Monograph on residue and contaminants in milk and milk products. Brussels (Belgium) chapter 6: 112-119.

Ivanov, A.; Evtugyn, G.; Budnikov, H.; Ricci, F.; Moscone, D. and Palleschi, G. (2003): Cholinesterase sensors based on screenprinted electrodes for detection of organophosphorus and carbamic pesticides. Anal Bioanal Chem., 377 (4): 624-631.

Kirkwood, B.R. (1989): Essentials of medical statistics, Blackwell Scientific Publication 2nd P.151.

Kituyi, E.N.; Wandiga, S.O. and Jumba, I.O. (1997): Occurrence of chlorfenvionphos residues in cow's milk sampled at a range of sites in Western Kenya. Bull. Environ. Contam. Toxicol., 58: 969-975.

Klaassen, C.D.; Amdur, M.O. and Doull, J. (1986): Cassarett and Doull's toxicology (The basic science of poisons), $3^{\text {rd }}$ ed., Macmillan Publishing Co., New York, Callier Macmillan Publishers, London, pp: 595-605.

Levensen, H. and Barnard, (1988): Wastes in Environment Hemisphere Public Coperation, Cambridge Lor. Pp. 123-129.

Licata, P.; Trombetta, D.; Cristani, M.; Gifore, F.; Martino, D.; Calo, M. and Naccari, F. (2004): Levels of toxic and essential metals in samples of bovine milk from various dairy farm in Calabria, Italy. Environ. Int. J., 30(1): 1-6.

Li, Y. and Wang, X. (1997): Study on the determination of Nmethylcabamate insecticides in milk by HPLC. Wei Sheng Yan. 
Jiu., 26(4): 278-282.

Mallatus, H.; Pappas, C.P.; Kondyli, E. and Albanis, T.A. (1997):

Pesticide residues in milk and cheeses from Greece. Sci. Total Environ., 196(2): 111-117.

Massanyi, P.P.; Nad, R. and Toman, J. (2001): Concentrations of cad mium, lead, nickel, copper and zinc in various muscles. Austrian Journal of Agric. Research. 52: 56-62.

Moretto, A. (1998): Experimental and Clinical Toxicology of anticholinesterase agents. Toxical Lett., 102-103; 509-513.

Naik, V.N.; Pandit, G.G.; Sharma, S.; Srivastava, P.K. and Mahon Rao, A.M. (2000): Organochlorine pesticide residues in milk and milk products in Mumbai. Proceedings of the National Symposium on the Environment. 5-7 June,; 254-257.

Pagliuca, G.; Gazzotti, T.; Zironi, E.; Pavocelli, N. and Rosmini, R. (2004): Proposal of an an alytical method for determination of residues of organophosphorus pesticides in milk by GLC-NPD. Vet. Res. Communi., 28: 257-259.

Salas, J.H.; Gon alez, M.; Noa, M.; Perez, N.A.; Diaz, G.; Gutierrez, R.; Zazueta, H. and Osuna, I. (2003): Organophosphorus pesticide residues in Mexican commercial pasteurized milk. J. Agric. Food Chem., 51: 4468-4471.

Simsek, O.; Gultekin, R.; Oksuz, O. and Kuruttary, S. (2000): The effect of environmental pollution on the heavy metal content of raw milk. Nahrung. J., 44(5); 360-363.

The European Commission (2003): Pesticide Residues: Maximum Residue Limits (MRLs).

Turi-szerletics, M.M. and Patko, I. (2008): Environmental Contaminants in Food stuffs. Acta Polytechnica Hungarica. Vol. 5: 135-140.

UNEP/ IOC/ IAEA. (1989): Determination of DDTs and PCBs by capillary gas chromatography / electron capture detection. Reference method for marine pollution studies. 40, UNEP.

WHO (1980): Technical Report Series. Recommended health based limits in occur-pational exposure to heavy metals. Report of a WHO study group. Technical reports Series, No. 631.

WHO (2005): Ensuring Food Safety in the Aftermath of Natural Disasters World Health Organization, Geneva. 